PROBLEMY WCZESNEJ EDUKACJI / ISSUES IN EARLY EDUCATION

ISSN 1734-1582

Vaiva Schoroškiene

https://doi.org/10.26881/pwe.2019.45.09

ORCID: 0000-0003-2735-3570

Vilnius University

vaiva.schoroskiene@gmail.com

\title{
Primary school students' argumentation skills: expression of arguments
}

\section{Summary}

This study was conducted to analyze the fourth grade students' linguistic abilities allowing them to express their arguments in oral and written texts: to determine both the number of presented arguments as well as the level of their elaboration, to characterize the expression of the arguments. The recorded number of participants was 117 fourth-graders from 15 Lithuanian schools. Oral and written texts created by the students were explored in the study. The obtained results revealed that the fourth grade students were able to voice their opinion on at least one argument when they created an oral or written text on a familiar topic and context. Approximately one-quarter of the study participants were able to present more than three arguments. No significant differences were found between oral and written argumentations with regard to quantity of the arguments. A qualitative analysis of the spoken and written texts indicates that the fourth grade students can use generalized statements (unelaborated secondary statements), they rely on examples and sources. It has also been observed that the study participants' abilities to develop arguments differ considerably. Their very diverse, even contrasting abilities demonstrate the necessity for developing/updating the curriculum content that would focus more on argumentation.

Keywords: argumentation skills, primary education, language development

Słowa kluczowe: umiejętność argumentowania, edukacja podstawowa, rozwój języka

\section{Introduction: context of the study}

Argumentation is a type of a text or a way to convey a meaning, when propositions are either approved or disapproved by presenting arguments (Ramoniené et al. 2012: 25). Scientific research relates the development of argumentation skills not only to mastering a native language, but also to the "development of thinking abilities of students of all ages: causal and scientific reasoning" (Kuhn 2009), "development of critical thinking” (Kuhn, Dean 2004), "development of the ability to construct your own knowledge" (Christodoulou, Osborne 2014). Christodoulou, Osborne (2014) consider evidence-based argumentation as a more efficient way of learning than instruction-based learning (Christodoulou, Osborne 2014). 
Argumentation skills are recognized to be important academic skills associated with discussions and debates in language development lessons (Kuhn, Crowell 2011; Deane, Song 2015). There are five stages of argumentation: understanding the issue, exploring the subject, considering positions, creating and evaluating arguments, organizing and presenting arguments. The dialogic approach encourages students to develop strategies for presenting several more complex arguments and to provide relevant evidence to support them. Students feel free to provide counterarguments and refute other students' arguments (Deane, Song 2015: 4; Chen et al. 2016). Lin (2014) admits that quality of argumentation strongly depends on the content and familiarity with argumentation structures and production processes. It is noted that even older students often make mistakes in evaluating the relevance of arguments. Thus, it is not enough to focus only on teaching models of argumentation - it is also crucial to teach students to recognize argumentation in written texts and critically evaluate it (Song et al. 2017).

The analysis of younger students' argumentation skills revealed their limited expression abilities. Therefore, when researching academic argumentation skills of 4-6-yearolds, more attention is paid to non-verbal argumentation (van der Graaf et al. 2015). When children reach older age, the spoken and written argumentation is combined. Evaluation and development of argumentation skills are integrated into engaging topics or subjects, for instance, in science education classes (van der Graaf et al. 2015; Chen et al. 2016).

In their review article, P. Deane and Y. Song (2015) laid a foundation for conducting research in the field of development of argumentation skills and proposed a system for their further development. The authors have observed that primary and middle school students demonstrate better argumentation in written texts. From the authors' perspective, oral and written argumentation skills should be developed as an integral whole and their development should already begin in pre-school, and consistently continue until high school. P. Deane and Y. Song (2015) state, that by the end of the second grade, students are only able to comprehend oral and very short written argumentations in familiar contexts. At this age students should grasp the idea of persuasion, learn how to evaluate other people's position by taking the presented arguments into consideration. They should also know how to defend their position and approach argumentation as a chain of arguments. Older primary school students are already able to support their opinion by providing at least one argument, yet their arguments can be affected by many factors, such as presentation of the assignment or students' personal reading experience. By the end of primary school students should know how to transfer the idea of a persuasive appeal into a written context and operate in an interesting and familiar context. Students of this age group must learn to understand and formulate their opinion in the written form, draw on their background knowledge, to recognize, create and elaborate written arguments in order to prove and express their opinion by coherently linking argumentative sentences. P. Deane and Y. Song (2015) assume that primary school students' limitations in argumentation are related to their lack of experience: students may face difficulties in planning argumentations, appealing to the audience. For example, they will possibly have stereotypical preconceptions or find it difficult to distinguish their personal opinion from general one. 
Primary school students' ability to present arguments should be developed systematically. At the end of second grade students should be able to generate at least one argument supporting their opinion and formulate it in a sentence. At the end of primary school they should already be able to generate multiple arguments, write short persuasive texts, where they combine arguments to form logical sequences and use appropriate connective words. However, even at the end of primary school students are likely to demonstrate limited abilities to evaluate and provide supporting evidence. Students may need help with specific questions or instructions. It is also likely that primary school students may lack flexible understanding; they may also have just a template-based grasp of argumentative text structures (Deane, Song 2015). The authors emphasize that empirical studies are necessary to verify these hypotheses.

In Lithuania, argumentation skills of primary school students are just starting to be researched. Educational programs are being updated, thus it is important to know what students of this age group are capable of.

The aim of this study is to investigate the fourth grade students' abilities to express arguments in oral and spoken texts:

- to determine the number of arguments presented and their elaboration;

- to characterize the expression of arguments.

\section{Methods}

Qualitative and quantitative analysis of oral and written texts.

\section{Participants}

The study participants were 117 fourth grade students from 15 Lithuanian schools located in seven cities of Lithuania. The students were chosen from 23 different classes. Based on teacher's recommendations, 3-6 students having different academic achievements were selected from each class.

\section{Procedure}

The study was carried out in 2015/2016. Oral and written texts created by the fourth grade students were analyzed. The participants were interviewed individually. The study consisted of two stages. First, the students were asked to choose one of the two given topics and create an oral argumentation. Then, they had to choose one of the other two given topics and create a written argumentation. Only the texts created exclusively by the students themselves, i.e. without influence of a researcher, were used in this study. In case the researcher had some influence on the student's text (e.g., if the student asked the researcher a question), only part of the text that had been created before the contribution of the researcher was used. In order to allow students to demonstrate their skills, given topics 
were related to their lives, and they could choose between two topics that proposed alternative opinions. The students were presented different though similarly formulated topics. Considering a stimulating effect the question „Why?" has on students (Christodoulou and Osborne 2014), it was decided to present the topic in a question form that starts with this word. Suggested topics are listed in Table 1.

Table 1. Topics suggested for the study participants

\begin{tabular}{|c|l|}
\hline Oral text & \multicolumn{1}{|c|}{ Written text } \\
\hline- Why are books better than computers? & - Why do children like reading in their spare time? \\
- Why are computers better than books? & - Why do not children like reading in their spare time? \\
\hline
\end{tabular}

Source: own elaboration.

The students' oral texts were written down by the researcher and the written texts were written down by the participants themselves. Due to the students' limited expression abilities some of the statements had to be reconstructed. In such cases, missing or clarifying words were presented in brackets. Afterwards, a qualitative analysis of oral and written texts was conducted. Oral and written texts were analyzed and grouped into subcategories and categories (Bitinas 2006: 272). The students created texts in their native language, i.e. Lithuanian. Examples provided in this study were translated to English.

\section{Results}

\section{Number of arguments and elaboration}

By analyzing the texts created by the students we aimed to determine how the fourth grade students were able to support their opinion. First of all, the number of arguments presented was analyzed. All the submitted texts were divided into four groups based on the number of arguments presented (Table 2).

Table 2. Number of arguments presented in the fourth grade students' texts

\begin{tabular}{|l|c|c|c|c|}
\hline \multirow{2}{*}{\multicolumn{1}{|c|}{ Opinion is supported by }} & \multicolumn{2}{c|}{ Oral texts } & \multicolumn{2}{c|}{ Written texts } \\
\cline { 2 - 5 } & $\begin{array}{c}\text { number } \\
\text { of students }\end{array}$ & $\%$ & $\begin{array}{c}\text { number } \\
\text { of students }\end{array}$ & $\%$ \\
\hline 1 argument & 18 & 16.1 & 37 & 31.9 \\
\hline 2 arguments & 38 & 33.9 & 28 & 24.1 \\
\hline 3 arguments & 30 & 26.8 & 22 & 19.0 \\
\hline More than 3 arguments & 26 & 23.2 & 29 & 25.0 \\
\hline In total & $112^{*}$ & 100.0 & $116^{*}$ & 100.0 \\
\hline
\end{tabular}

* 1 student did not create a written text and 5 students did not create oral texts.

Source: own elaboration. 
Data analysis shows that the students who participated in the study were able to support their opinion by presenting at least one argument. It should be pointed out that, the number of students who presented only one argument in the written texts was twice as big $(31.9 \%)$ as in oral texts $(16.1 \%)$. When analyzing the texts where only one argument was provided, it was apparent how strongly the students' abilities to elaborate their arguments differ. For example:

No. 11 Children don't like it, because they play on their phones, computers and TVs. $(b, w)^{*}$

No. 73 Books are better than computers, because they allow our imagination to develop properly. Especially fantasy books make you think and give you many ideas. It would be fun to write a book myself. I have even created some fantasy stories. $(g, o)$

No. 5 Why do not children like reading.

Nowadays children don't like reading because they think computers are more important and better. Back in the day there were no computers, but they don't care. Children say:

- We are modern children and we don't like reading.

I advise everyone to read books. $(g, w)$

1 unelaborated argument (underlined)

1 argument; elaborated by adding a couple of sentences about herself.

1 argument; elaborated by several sentences, direct language and paragraphs are used.

* The quotation includes research participant's number and the type of text (w - written, o - oral).

Although the length of the students' texts is not the most important indicator of argumentation quality, yet we have taken it into consideration when giving examples to reveal the variety of texts. Ten very short texts, i.e., up to ten word texts were created (five oral and five written) where arguments are unelaborated. Meanwhile, the analysis of the longest texts, where one argument was provided, demonstrated that the length had been influenced by limitations of students' expression skills (e.g., unnecessary repetitions and the lack of conciseness were noticed in the oral texts), or by longer introductions and conclusions. Furthermore, introductions and conclusions of the written texts seemed to be more natural and thought-through. It is likely that the process of creating texts in spoken situations was more spontaneous, therefore, repetitions and topic shifting were more frequent.

Now we will present some of the shortest and longest texts, where opinion is supported by one argument. For example:

No. 28 Because there are games in computers. $(g, o, 6 w .)^{*}$

No. 95 Maybe books. Books are better, because you learn many things. $(\mathrm{g}, \mathrm{o}, 10 \mathrm{w}$.)

No. 98 Because they're lazy. (b, w, 3 w.)

No. 70 Because they don't want to be called bookworms. ( $g, w, 8$ w.)

The shortest

texts

(henceforth, arguments are underlined) 
No. 106 Why do not children like reading in their spare time? Because in their spare time children like to play and not to read books. They have most spare time during winter and summer. In summer it's very warm and all friends are outside. That's why children go outside, play, buy and of course eat ice cream. And in winter children want to go outside, because there's lots of snow outside and most children, almost all of them, want to play with the snow, little kids sometimes even want to try tasting it. So, if we compare all this fun to books, reading is a real drag. (b, w, 106 w.)

* The quotation includes research participant's number, the type of text ( $\mathrm{w}$ - written, o - oral) and number of words.

The majority of the students who participated in the study presented from two to three arguments. It should be noted that the arguments in such texts were elaborated in very different ways. It is likely that this was influenced by the research method: participation in an interview encouraged students to provide more arguments and elaborate on them less, while the written task motivated them to expand more on a particular argument. The shortest texts demonstrate barely elaborated or completely unelaborated arguments. In the longest texts, we notice widely elaborated arguments as well as the cases of irrelevant talk. For example:

No. 36 Books are better, because they don't damage your eyes, and my mother says that books develop your creativity and imagination. (g, o, $20 \mathrm{w}$.)

No. 108 I was probably the only one to choose the topic that computers are better than books. Of course you can find a lot of information about animals, countries, and people in books, but I still believe that computers are better because there you can find information very quickly. You can also find a lot of new information on a computer, while if a book is old, we won't find new information and will have to use the computer. $(g, o, 78 \mathrm{w}$.)

2-3 poorly elaborated arguments 2-3 elaborated arguments

Some students who participated in the study tried to provide as many arguments as possible. However, even in the texts with more than three arguments, we noticed the contrast in length. The shortest texts in this group contain approximately 20 words (oral texts - 22, 28 words; written - 12, 13 words. The listed number of words is based on the original language the texts were created in, i.e., Lithuanian). The arguments in these texts are simply listed with no traces of elaboration. The longest texts in this group demonstrate not only elaborated arguments, but also structural decisions, the use of stylistic devices, for example, they include introduction and conclusion. The longest oral texts in this group contained 76, 77 words, and written - 126, 124 words. The following examples demonstrate the most evident contrasts:

No. 20 Why do not children like reading in their spare time?/Because they want to play on the computer. They want to meet friends. Watch TV. They're lazy. $(g, w, 17 w$.

Example

of poorly

elaborated

arguments

(shortest text) 
No. 46 Spare time is when we relax. Most kids who are calm like reading books. They understand that in books you can find the wisdom of our elders, and books are better than computers, that's exactly what I think. Books tell the beginning of historical times or the beginning and end of various discoveries. Books help us to learn about the world, experience adventures or develop our imagination.

But there are children and people who do not like reading books. They think computers are better than books. Although on the computer you can find dates of some things. Because, for example, we are on the Internet looking for the beginning and the end of historical events. But where there're supposed to be historical events, we find information about the area of Lithuania, and not historical events. But there are kids who think that playing computer games is more interesting than learning about Lithuanian history. $(g, w, 153 w$.)

Example of elaborated arguments (longest text)

To sum up, all the students participating in the study were able to support their opinions with at least one argument, but only some students were able to elaborate on them. The analysis of the texts indicates that some students try to provide as many different arguments as possible, but they do not expand them. It is likely that the students do not clearly understand what is considered to be a good argument. The analysis of the students' texts also suggests that the students with weaker academic skills create shorter texts and elaborate them less, they also do not use stylistic devices. A more detailed research is needed to support this statement.

\section{Expression of an argument in the fourth grade students' argumentations}

We also analyzed the arguments presented in the students' oral and written texts. If there were several arguments in one text, we analyzed them separately. We aimed at determining the diversity of arguments. By conducting a qualitative analysis of arguments, we divided all the arguments into groups, created subcategories and categories (Table 3).

Table 3. Expression of arguments in the fourth grade students' argumentations

\begin{tabular}{|c|c|c|}
\hline Group description & Subcategory & Category \\
\hline $\begin{array}{l}\text { Language is generalized, vague, expressed in the Passive voice. E.g.: } \\
\text { No. } 1 \text { Because computer damages eyes and brain. }(g, o) \\
\text { No. } 23 \text { (...) Also, you can train your brain when you read, so it gets } \\
\text { easier to solve crossword puzzles. }(b, w)\end{array}$ & $\begin{array}{l}\text { Generalized } \\
\text { statements } \\
\text { similar to } \\
\text { shorter } \\
\text { theses, that } \\
\text { are not being } \\
\text { proved/ } \\
\text { elaborated }\end{array}$ & $\begin{array}{l}\text { Generalized } \\
\text { statements }\end{array}$ \\
\hline
\end{tabular}


Table 3. cont.

\begin{tabular}{|c|c|c|}
\hline Group description & Subcategory & Category \\
\hline $\begin{array}{l}\text { Talks about ,us" E.g.: } \\
\text { No. } 2 \text { Because books give us knowledge... }(g, o) \\
\text { No. } 64 \text { (...) when we're reading a book, we're not damaging our } \\
\text { eyes. And computer damages. }(g, w)\end{array}$ & & \\
\hline $\begin{array}{l}\text { Talks in } 3^{\text {rd }} \text { person as referring to classmates, peers (children/they... } \\
\text { think/do...). E.g.: } \\
\text { No. } 4 \text { (...) children don't know how many great things you can } \\
\text { find in books. (b, r.) } \\
\text { No. } 1 \text { (...) Children have very young brains, and brain cells die } \\
\text { when kids play too much on computers or phones. }(. . .)(g, w)\end{array}$ & & \\
\hline $\begin{array}{l}\text { Talks about himself, does not generalize (constructions for me, } \\
\text { me, I...; mentions what happened to him, what he saw, felt, } \\
\text { experienced). E.g.: } \\
\text { No. } 37 \text { Because sometimes I get bored, my legs and arms get numb, } \\
\text { I become hungry and children have other things to do. }(b, w) \\
\text { No. } 22 \text { I love books about Harry Potter because I like horror } \\
\text { stories, monsters. }(g, w)\end{array}$ & $\begin{array}{l}\text { Refers to } \\
\text { personal } \\
\text { experience }\end{array}$ & $\begin{array}{l}\text { Gives } \\
\text { arguments } \\
\text { by providing } \\
\text { examples }\end{array}$ \\
\hline $\begin{array}{l}\text { Talks about, ,you". E.g.: } \\
\text { No. } 2 \text { (...) Also. Books don 't need electricity. And if you become } \\
\text { addicted to computer, then you will have to pay four times } \\
\text { more at the end of the month than usual. }(g, w)\end{array}$ & \multirow{2}{*}{$\begin{array}{l}\text { Possibly } \\
\text { gives } \\
\text { arguments } \\
\text { by providing } \\
\text { examples }\end{array}$} & \\
\hline $\begin{array}{l}\text { After generalization lists some details that resemble examples, but } \\
\text { does not use the phrase, ,for example". E.g.: } \\
\text { Nr. } 59 \text { (...) more information can be more easily found than in } \\
\text { books. And you can find the information faster, because if } \\
\text { you need a dictionary, then you can keep turning the pages, } \\
\text { while on the computer you can easily find the word you 're } \\
\text { looking for, like in two seconds. (g, o) }\end{array}$ & & \\
\hline $\begin{array}{l}\text { Uses phrases, ,for example”, ,let's say". E.g.: } \\
\text { No. } 1 \text { (...) let's say, fantasy books are created and on the computer } \\
\text { you can't read books. (g, o) } \\
\text { No. } 80 \text { For example, I want something to drink, I'm thirsty, my } \\
\text { favorite show is on } T V .(b, w)\end{array}$ & \multirow[t]{2}{*}{$\begin{array}{l}\text { Gives } \\
\text { arguments } \\
\text { by providing } \\
\text { examples }\end{array}$} & \\
\hline $\begin{array}{l}\text { Personal experience is given as an example after a generalized } \\
\text { statement. E.g.: } \\
\text { No. } 45 \text { (...) Children who like reading, are quite calm, and those } \\
\text { who don't like reading are naughty. For example, I like } \\
\text { reading and having fun. }(g, w) \\
\text { No. } 38 \text { There is more information, videos on the computer. It's } \\
\text { more interesting, more fun. I (= for example) always find } \\
\text { something to do on the computer. I like playing computer } \\
\text { games. }(b, o)\end{array}$ & & \\
\hline
\end{tabular}




\begin{tabular}{|c|c|c|}
\hline Group description & Subcategory & Category \\
\hline $\begin{array}{l}\text { Mistake is made when using a word or an expression. E.g.: } \\
\text { No. } 19 \text { Books are better than computers, because you find more } \\
\text { knowledges (= knowledge) in books. (b, s) } \\
\text { No. } 31 \text { (...) It expands your vocabulary and you drive (= dive) into } \\
\text { a reading adventure. (...) }(b, s)\end{array}$ & \multirow[t]{4}{*}{$\begin{array}{l}\text { Possibly uses } \\
\text { a source, } \\
\text { but it is not } \\
\text { specified }\end{array}$} & \multirow[t]{4}{*}{$\begin{array}{c}\text { Uses } \\
\text { a source }\end{array}$} \\
\hline $\begin{array}{l}\text { Uses well known and often used phrases and expressions (clichés, } \\
\text { figurative expressions) E.g.: } \\
\text { No. } 41 \text { Dives into the world of adventures. ( } g \text {, w) } \\
\text { No. } 43 \text { (...) Spends time with modern children's best friend } \\
\text { computer, instead of their family members. (...) they sit } \\
\text { there and grow their bellies growing even lazier. }(g, w)\end{array}$ & & \\
\hline $\begin{array}{l}\text { Use phrases, expressions that are uncommon to children. E.g.: } \\
\text { No. } 1 \text { Children have very young cells, and brain cells die when } \\
\text { kids play too much on computers or phones }(. . .) .(g, w) \\
\text { No. } 15 \text { (...) that's why so many kids wear glasses and their body } \\
\text { weight increases. }(g, w)\end{array}$ & & \\
\hline $\begin{array}{l}\text { A story is included (e.g. about how the role of books has changed). E.g.: } \\
\text { No. } 73 \text { Because computers were created and they replaced books, } \\
\text { because people used to want to read. But when technology } \\
\text { appeared, like computers, TVs, phones and etc., people } \\
\text { started to read less because they were only playing on } \\
\text { computers and phones. Out of } 100 \text { percent only } 50 \text { percent } \\
\text { of people still read (in my opinion) (...). }(g, w)\end{array}$ & & \\
\hline $\begin{array}{l}\text { Intonation suggests that something is being quoted (source } \\
\text { unspecified). E.g.: } \\
\text { No. } 46 \text { Book is wisdom, tells historical events. }(g, o)\end{array}$ & \multirow[t]{4}{*}{$\begin{array}{l}\text { Emphasizes } \\
\text { that a source } \\
\text { is used }\end{array}$} & \\
\hline $\begin{array}{l}\text { Author of the book, characters and events are mentioned. E.g.: } \\
\text { No. } 81 \text { (...) Hans Christian Andersen's fairytales are interesting all } \\
\text { over the world. Fiction stories, poems can be found there } \\
\text { (= in books). Usually children read his fairytales about the } \\
\text { Ugly Duckling, the Snow Queen. }(b, w)\end{array}$ & & \\
\hline $\begin{array}{l}\text { Sources are specified (mother, teacher...). E.g.: } \\
\text { No. } 89 \text { (...) Teacher said that reading helps you to write essays } \\
\text { quicker and better (...). (g,o) }\end{array}$ & & \\
\hline $\begin{array}{l}\text { Emphasizes a wish to specify the source as accurate as possible. E.g.: } \\
\text { No. } 107 \text { One article that was called, if I remember correctly , Will } \\
\text { computers replace books?" (...) I read that computers can } \\
\text { be more useful in some areas than books. }(g, o)\end{array}$ & & \\
\hline
\end{tabular}

Source: own elaboration. 


\section{Discussion}

Although the study sample size does not allow us to make generalizations on a national level, yet, it still confirms some statements made by other researchers. For example, the study results confirm Deane, Song (2015) hypothesis about primary school students' ability to support their opinion by providing at least one argument in argumentation. Decision to analyze oral and written texts together was also proven to be a correct approach: no significant differences were noticed when analyzing the fourth grade students' texts.

The focus in this study lies on the fact, that the students tended to give as many arguments as possible, and also revealed their limited abilities to give elaborate arguments. The study showed that the fourth grade students had been able to provide an $\operatorname{argument}(\mathrm{s})$, however, not all of them. We link this finding to the students' settled way of thinking (e.g., what argumentation is considered to be good?) and the lack of knowledge about the structure of arguments, argumentative texts. Rather significant differences in students' skills can be explained by the fact that these abilities were not systematically developed at Lithuanian schools during the study. It is likely that the contrast of abilities will decrease with the development of school programmes and their contents in this field. Nevertheless, it should be noted that the students' skills surpassed content of the updated curriculums. We believe that the development of argumentation skills during different lessons and other innovations in this field indicate that it is necessary to systematically introduce students to more diverse argumentation models, options.

It is important to take limitations of the study into consideration when analyzing the results. They have possibly had some impact on the study results. For example, students were more spontaneous when creating oral texts than written ones. Individual interviews with the researcher might have encouraged students to provide more arguments, but to elaborate on them less. However, the chosen topic proved to be appropriate for both the study and the students: familiar context allowed the students to focus on the content and demonstrate their expression abilities. We believe that it would be useful to compare the results of this study to a similar study where students were asked to provide arguments on another topic. This would allow us to have a more objective view of the students' abilities. Another limitation of this study is linked to the students' age and expression. For example, it was not always easy to identify when the student was constructing his argumentation only on his/her personal experience, and when the things he/she learned/heard were expressed as their personal experience; the students would leave out some words, change the usage of personal pronouns.

The suggested subject for further studies in this field is correlation between students' argumentation skills and students' academic abilities. The analysis suggests that students with stronger academic skills create longer texts, provide more arguments, elaborate a higher number of arguments more and apply stylistic devices. 


\section{Conclusion}

The research suggests that the fourth grade students are able to base their opinion on at least one argument when creating spoken or written argumentative texts in familiar contexts and when discussing familiar topics. It has been observed that the students' abilities to elaborate arguments are very different, even contrasting.

The majority of the students who participated in the study provided more than one argument. In the oral texts, the majority of the students (34\%) provided two arguments, while in the written texts most of the students (32\%) provided one argument. More than three arguments were given in a similar percentage of the oral and written texts $(23 \%$ and $25 \%$ ). In terms of quantity, there were no significant differences between the oral and written arguments.

A qualitative analysis of the oral and written texts demonstrates that the fourth grade students provide arguments in a form of generalized statements (unelaborated secondary statements), they use examples and sources. Some students lack the ability to do this properly. We believe that these difficulties emerged due to the students' expression abilities and due to the lack of systematic education.

\section{References}

Bitinas B. (2006), Edukologinis tyrimas: sistema ir procesas. Vilnius, Kronta.

Chen Y.-C., Hand B., Park S. (2016), Examining Elementary Students'Development of Oral and Written Argumentation Practices Through Argument-Based Inquiry. "Science and Education", 25.

Christodoulou A., Osborne J. (2014), The Science Classroom as a Site of Epistemic Talk: A Case Study of a Teacher's Attempts to Teach Science Based on Argument. "Journal of Research in Science Teaching", 51(10).

Deane P., Song Y. (2015), The Key Practice, Discuss and Debate Ideas: Conceptual Framework, Literature Review, and Provisional Learning Progressions for Argumentation. Research Report ETS RR-15-33. https://files.eric.ed.gov/fulltext/EJ1109288.pdf, 21.09.2018.

Kuhn C., Crowell A. (2011), Argumentation as a Path to the Thinking Development of Young Adolescents. Society for Research on Educational Effectiveness (SREE) Reports. https://eric. ed.gov/?id=ED519122, 21.09.2018.

Kuhn D. (2009), Do students need to be taught how to reason? "Educational Research Review", 4.

Kuhn D., Dean J. (2004), Metacognition: A Bridge Between Cognitive Psychology and Educational Practice. "Theory Into Practice", 43(4).

Lin S.-S. (2014), Science and non-science undergraduate students' critical thinking and argumentation performance in reading a science news report. "International Journal of Science and Mathematics Education", 12.

Ramonienė M., Brazauskienė J., Burneikaitė N., Daugmaudytė J., Kontutytė E., Pribušauskaitė J. (2012), Lingvodidaktikos terminu žodynas. Vilnius, Vilniaus Universiteteo Leidykla.

Song Y., Deane P., Fowles M. (2017), Examining Students'Ability to Critique Arguments and Exploring the Implications for Assessment and Instruction. Research Report ETS RR-17-16. https://files.eric.ed.gov/fulltext/EJ1168598.pdf. 21.09.2018.

Van der Graaf J., Segers E., Verhoeven L. (2015), Scientific reasoning abilities in kindergarten: dynamic assessment of the control of variables strategy, "Instructional Science", 43. 